\title{
Revolta e cidadania na Corte regencial*
}

\section{Marcello Basile*}

Este artigo analisa a revolta ocorrida no teatro São Pedro de Alcantara, no Rio de Janeiro, em setembro de 1831. Trata-se de um movimento político promovido pela facção dos liberais exaltados, com participação de camadas sociais diversas. Situada no conjunto de outras ações semelhantes, verificadas no início do período regencial, é compreendida como um dos eixos de desenvolvimento de uma cidadania informal e de uma incipiente nacionalidade, construídas de baixo para cima, no âmbito de um emergente espaço público de ação política.

Palavras-chave: Revolta - Cidadania - Regência

Rebellion and citizenship in Rio de Janeiro's Court during the Regency

This article analyzes the rebellion that took place in the São Pedro de Alcantara Theatre, Rio de Janeiro, in September 1831. That was a political uprising conducted by the liberais exaltados in which several different social layers also took part. The movement was similar to others that took place in the beginning of the Regency period. It is also understood as one of a set of axles for informal citizenship development and an incipient sense of nacionality. Both were forged from below in an emergent political action public space.

Keywords: Rebellion - Citizenship - Regency

* Artigo recebido em outubro de 2006 e aprovado para publicação em dezembro de 2006. Ele é uma versão da seção 2 do capítulo IX de minha Tese de Doutorado, intitulada "O Império em construção: projetos de Brasil e ação política na Corte regencial”, Rio de Janeiro, PPGHIS-UFRJ, 2004.

** Professor Adjunto de História do Brasil da Universidade Federal Rural do Rio de Janeiro

- Instituto Multidisciplinar. E-mail: marcellobasile@ig.com.br. 
Rébellion et citoyenneté dans la Cour de Rio de Janeiro pendant la Régence Cet article analyse la rébellion qui a eu lieu au Théâtre São Pedro de Alcantara, à Rio de Janeiro, en septembre 1831. Il s'agit d'un soulèvement politique encouragé par la faction des libéraux exaltés ayant la participation des diverses couches sociales. Située dans l'ensemble d'autres actions semblables qui se sont produites au début de la période de la Régence, cette rébellion est vue ici comme étant un des axes du développement d'une citoyenneté informelle et d'une nationalité embryonnaire, construites à partir de la base, dans un espace public naissant d'action politique.

Mots-clés: Rébellion - Citoyenneté - Régence

Rio de Janeiro, 1831. Com cerca de 150 mil habitantes, a capital do Império era um grande caldeirão político e social em ebulição. A chamada Revolução de 7 de Abril forçara a abdicação do primeiro imperador e instituíra uma regência trina para governar a nação até a maioridade de Pedro II. Desde então, a arena política encontrava-se acirradamente dividida em três facções, que disputavam o poder (e os cargos públicos), dotadas de princípios e propostas bastante distintos: na posição de centro, os liberais moderados, que controlavam o novo governo e tinham maioria na Câmara dos Deputados; à esquerda, os liberais exaltados, que promoveram, ao lado dos primeiros, o movimento da Abdicação, mas foram logo alijados e perseguidos, gozando de fraca representação parlamentar; e, à direita, os caramurus, simpatizantes do ex-imperador, que tinham forte apoio no Senado. ${ }^{1}$ Entrecruzando com as

\footnotetext{
${ }^{1}$ Os moderados seguiam os postulados clássicos do liberalismo, tendo em Locke, Montesquieu, Guizot e Constant suas principais referências; pretendiam, e conseguiram, efetuar reformas político-institucionais que reduziam os poderes do imperador, conferiam maiores prerrogativas à Câmara dos Deputados e autonomia ao Judiciário, e garantiam a observância de direitos previstos na Constituição, almejando uma liberdade moderna, que não ameaçasse a ordem imperial. Já os exaltados, adeptos de um liberalismo radical de feições jacobinistas, inspirado sobretudo em Rousseau, buscavam conjugar princípios liberais clássicos com ideais democráticos, pleiteando profundas reformas políticas e sociais, como uma república federativa, a extensão da cidadania política e civil a todos os segmentos sociais livres, o fim gradual da escravidão, uma relativa igualdade social e até um tipo de reforma agrária. Por sua vez, os caramurus filiavam-se à vertente conservadora do liberalismo, tributária de Burke; críticos ferozes da Abdicação e avessos a qualquer reforma na Constituição, vistas como quebra arbitrária do pacto social, almejavam uma monarquia constitucional fortemente centralizada, ao estilo do Primeiro Reinado e, excepcionalmente, nutriam anseios restauradores. Sobre esses projetos e seus defensores, ver Marcello Otávio Neri de Campos Basile, "O Império em construção...”, op. cit., capítulos I, II, V, VI, VII e XI; e Marco Morel, As transformações dos espaços públicos: imprensa, atores políticos e sociabilidades na cidade imperial (1820-1840), São Paulo, Hucitec, 2005, capítulo 3.
} 
disputas políticas, uma série de outros elementos explosivos agitava a vida da cidade. Militares de todos os escalões ressentiam-se com as críticas às constantes intervenções políticas (contra ou a favor do governo) das forças armadas e o decorrente desprestígio das corporações; com a redução dos efetivos e as habituais transferências de unidades para outras regiões; com as suspensões, as baixas compulsórias e as prisões dos envolvidos em distúrbios; com os ínfimos soldos, o recrutamento forçado e os castigos corporais. No plano econômico, uma grave crise arrastava-se desde o início do Primeiro Reinado, agravada pelo problema alarmante da falsificação e da falta de moedas de cobre, provocando carestia e alta do custo de vida (especialmente no preço dos aluguéis de imóveis e dos alimentos). Além disto, a população fluminense achava-se marcada profundamente por clivagens sociais, étnicas e nacionais, evidenciadas nas disputas cotidianas pelo mercado de trabalho, nas rivalidades entre brasileiros e portugueses (ou estrangeiros em geral) e nas múltiplas faces do espectro haitianista. Em meio às disputas entre as facções, todos estes elementos eram explorados e amplificados, assumindo cunho eminentemente político e ensejando a luta pela conquista de direitos.

Foi este ambiente conturbado - mas também dos mais ricos e singulares em termos de experiências políticas e sociais - o palco de vários movimentos de protesto e revolta sucedidos na Corte, entre 1831 e 1833. O movimento aqui analisado - o distúrbio desencadeado no teatro São Pedro de Alcantara (atual João Caetano, na então praça da Constituição, hoje Tiradentes), nos dias 28 e 29 de setembro de 1831 - foi o segundo de uma série de oito durante a Regência, iniciada com a sedição do Povo e Tropa, de 12 a 20 de julho daquele ano, e prosseguindo com as revoltas de 7 de outubro, 3 e 17 de abril de 1832, 12 e 25 de setembro do mesmo ano e de dezembro de $1833 .^{2}$

\footnotetext{
${ }^{2}$ Ver, a respeito, Marcello Otávio Neri de Campos Basile, "O Império...”, op. cit., caps. IX, X, XIII e XIV. A historiografia tem dado muito pouca atenção a esses movimentos e a vários outros nas províncias. A revolta em questão, por exemplo, só foi abordada em outros dois trabalhos, além do já citado: um artigo pioneiro de Moreira de Azevedo, que, no entanto, reproduz e reitera a versão oficial e moderada do distúrbio; e uma breve análise de Gladys Ribeiro, circunscrita, porém, à questão do antilusitanismo presente nos acontecimentos. Cf. Manuel Duarte Moreira de Azevedo, "Os tiros no theatro: motim popular no Rio de Janeiro", Revista trimensal do Instituto Historico, Geographico e Ethnographico do Brasil, t. XXXVI, parte 2, Rio de Janeiro, Typ. Imparcial, 1873; e Gladys Sabina Ribeiro, A liberdade em construção: identidade nacional e conflitos antilusitanos no Primeiro Reinado, Rio de Janeiro, Relume Dumará/FAPERJ, 2002, p. 290-293.
} 


\section{Prontos para tudo: a revolta do teatro São Pedro de Alcantara}

A bem-sucedida repressão do governo à revolta de julho de 1831 foi seguida de um conjunto de medidas preventivas para desencorajar outra sedição. A principal foi a criação, a 18 de agosto, da Guarda Nacional, cuja proposta precedia aquela revolta, mas foi logo aprovada, em decorrência direta desse movimento e da instabilidade política e social que grassava em todo o Império. Outra ação foi a tentativa de coagir e silenciar os jornais exaltados, tidos como principais promotores das agitações. O mais importante deles, a Nova Luz Brasileira, redigida pelo boticário Ezequiel Corrêa dos Santos, sofreu processo por abuso da liberdade de imprensa, ao pregar a adoção de uma república democrática, nos moldes da federação do Equador. Sintomaticamente, a edição acusada (154), aceita pelo Júri de 25 de agosto por maioria de votos, foi publicada em plena revolta, a 20 de julho. O jornal denunciou diversas arbitrariedades cometidas na execução do processo para condenálo, como a substituição do promotor Basilio Ferreira Goulart, que "se não quis dobrar às inconstitucionais Portarias do Sr. Feijó contra a Liberdade da Imprensa", pelo promotor Ouvidio Saraiva de Carvalho, que "não possui a necessária independência d'um Membro do Poder Judicial"; e uma pretensa trapaça no sorteio dos jurados, pois os escolhidos eram funcionários públicos e, logo, dependentes do governo. ${ }^{3}$ Mas o jornal foi unanimemente absolvido, a $1^{\circ}$ de setembro, assim como outras duas folhas exaltadas, A Voz da Liberda$d e$, redigida por Miguel de Frias e Vasconcellos, e $O$ Republico, de Borges da Fonseca, também processados no mesmo período, igualmente por atentado à liberdade de imprensa. ${ }^{4}$

\footnotetext{
${ }^{3}$ Nova Luะ Brasileira, $\mathrm{n}^{\circ} 163$ - 27/8/1831. Goulart foi processado (a mando do ministro da Justiça, Diogo Feijó) e condenado em primeira instância por crime de responsabilidade no emprego público, ao não acusar a folha exaltada. Em seu recurso ao Tribunal da Relação - que o absolveu - alegou que fizera a acusação a 17 de agosto, quatro dias depois de suspenso por Feijó, não tendo feito antes por falta de tempo. Diario do Rio de Janeiro, n ${ }^{\circ} 9-12 / 12 / 1832$. Sobre a Nova Luz Brasileira e seu redator, ver Marcello Otávio Basile, Ezequiel Corrêa dos Santos: um jacobino na Corte imperial, Rio de Janeiro, Fundação Getúlio Vargas, 2001.

${ }^{4}$ Cf. ANÔNIMO, Hymno Dedicado, pelos Jovens Fluminenses, aos Illustres Redactores do Republico, Voz Ė Nova Luz por Occasião de sua Absolvição no Tribunal do Jury (Anônimo), Rio de Janeiro, Typ. de Lessa \& Pereira, 1831, que exalta a absolvição dos "Gênios da LIBERDADE" pelo “TRIBUNAL DA RAZÃO”. O jornal O Exaltado (n 5 - 10/9/1831) também saudou a absolvição do "intrépido defensor de suas liberdades; o Redator da Nova Luz", "folha Patriótica, corajosa, e inabalável", como um triunfo da liberdade sobre os arbítrios de Feijó.
} 
Outras medidas preventivas foram tomadas pelo governo para conter a agitação na Corte. ${ }^{5}$ Contudo, não surtiram o efeito desejado. Desde fins de julho e durante todo o mês de agosto corriam rumores de que nova revolta estaria sendo tramada e eclodiria a qualquer hora. Já em 29 de julho, o jornal moderado O Independente informava que, segundo boatos, soldados de vários batalhões, "ajudados d'alguns mal intencionados", estariam prontos a pegar em armas, havendo até desaparecido do quartel o armamento do Corpo de Polícia, extinto por sua participação na revolta de julho; além disto, as armas que pertenceram aos soldados transferidos para outras províncias ou que deram baixa forçada se conservavam ainda nos quartéis, e não recolhidas ao Arsenal de Marinha. O jornal cobrava, então, ações mais enérgicas do governo para combater a anarquia, pois,

Se por desleixo, ou inaptidão das autoridades as cenas de 14 e 15 se houverem ainda de repetir, se os criminosos violadores das leis houverem de ficar entre nós impunes, podemos dizer que temos um Governo? Não. Será preciso que cada cidadão cure da sua própria segurança.

Onze dias depois, embora elogiando a prisão de vários amotinadores nas últimas noites, o mesmo jornal reclamava que "boatos aterradores, que de vez em quando se espalham por esta Capital, e que anunciam rusga para tal ou tal dia, não têm cessado depois do meado do mês passado". ${ }^{6}$

Na noite de 20 de agosto, soldados do Esquadrão da Cavalaria de Minas insubordinaram-se, saindo dos quartéis armados e sem ordem do comandante, em direção a São Cristóvão, no intuito de voltarem à sua província. No caminho, todavia, foram alcançados pelo comandante, que os convenceu a se aquietar, mediante promessas feitas pelo regente Lima e Silva. Segundo O Independente,

(...) a criminosa insurreição da Polícia, e dos soldados d'outros corpos da guarnição desta Cidade concorreu muito para fazer com que o esquadrão desse aquele passo indesculpável, o qual (...) espalhou o susto por entre as famílias

\footnotetext{
$\overline{{ }^{5} \text { Como a distribuição, ordenada por Feijó em } 30 \text { de julho, de armas e munição a cerca de três }}$ mil cidadãos eleitores, para realizar rondas diárias; a permanência da suspensão das cartas de seguro, aprovada pela Câmara; o corte, por lei de 30 de agosto, no efetivo do Exército para no máximo dez mil homens em todo o país.

${ }^{6}$ O Independente, $\mathrm{n}^{\text {os }} 26$, de 29/7/1831, e 29, de 9/8/1831. Ver também carta na Astréa $\mathrm{n}^{\circ} 735$, de 20/8/1831.
} 
dos Fluminenses, fazendo correr às armas grande número de guardas Cidadoas, que acudiram ao som das matracas. ${ }^{7}$

Foi neste clima que, por ocasião das comemorações do 7 de Setembro, se espalhou um grande boato de que os exaltados estariam preparando uma rebelião sangrenta para o dia do aniversário da Independência. $\mathrm{O}$ alarde foi gerado por uma polêmica e virulenta correspondência publicada no Diario do Rio de Janeiro, em 3 de setembro, assinada por Hum que está prompto para tudo:

Hoje ninguém deve dormir. Os chamados Salvadores da Pátria, que dizem morta porque assim a desejam ver, maquinam tramas por toda a casta de meios, para verem realizados seus intentos! A dias falam eles que o dia 7 do corrente, é quando devem principiar os assassinatos! (...) Venham eles; não os tememos. Se a Pátria tem inimigos, tem ainda mais amigos; podemos contar com dez mil espingardas; e baste que cada um das janelas dê o seu tirinho, não chega uma perna para cada espingarda; temos muita telha pelos telhados para escovar-lhes as cabeças; e muitos honrados Militares, que lá os irão buscar ao Campo se aí se quizessem acantonar. Vamos já decidir este negócio, e viva quem vencer. Os tais de faca e punhal poderão assassinar a alguém; mas estamos firmes, e temos jurado, que por uma vítima da Pátria hão de ser sacrificados cem anarquistas; nós os conhecemos. O Governo não alegue depois ignorância.

O correspondente ainda mencionava alguns endereços na cidade, onde morariam ou se reuniriam "alguns dos assassinos mais notáveis". ${ }^{8}$ A carta desencadeou grande polêmica. Já na edição seguinte do jornal, o juiz de paz da freguesia do Sacramento, Saturnino Luiz de Oliveira, pedia ao missivista para o procurar, a fim de "falar sobre o objeto do mesmo anúncio", garantindo-lhe "inviolável segredo"; outro correspondente, O Saberete, morador da rua do Espírito Santo (um dos endereços apontados pelo polemista), o interpelava, desconfiado, para que declarasse "quem é o indivíduo anarquista de faca, e punhal que cita na sua correspondência". ${ }^{9}$ O mesmo fazia, no dia seguinte, O que está pronto só para o bem da Patria, também morador de um dos locais denunciados, que pedia ao autor daquela carta "verdadeiramente Anárqui-

\footnotetext{
${ }^{7}$ O Independente, $\mathrm{n}^{\circ} 33$, de 23/8/1831. Os grifos de todas as citações encontram-se nos textos originais. ${ }^{8}$ Ruas do Sabão (avenida Presidente Vargas), do Alecrim (Buenos Aires), do Espírito Santo (Pedro Primeiro), dos Inválidos, do Cano (Sete de Setembro), da Quitanda, da Guarda Velha (avenida Treze de Maio), do Senado, das Mangueiras (Visconde de Maranguape), do Valongo (Camerino) e da Conceição, beco do Costa (rua Alexandre Mackenzie) e largo da Sé (praça Monte Castelo); Diario do Rio de Janeiro, no 3, de 3/9/1831.

${ }^{9}$ Ibidem, n ${ }^{\circ} 4$, de 5/9/1831.
} 
ca" que declarasse "quais as pessoas que ele anunciante tem notícia que se acham tramando"; além disto, requeria aos juízes de paz que convocassem o denunciante para prestar esclarecimentos e sugeria ao promotor do Júri que o levasse a jurados. ${ }^{10}$

Nesse mesmo dia, o Conselho da Sociedade Defensora, associação política moderada, convocou seus sócios residentes na freguesia do Sacramento a se apresentarem aos respectivos comandantes de esquadra para formar a Guarda de Rondas Municipais, que deveria ficar de prontidão no largo de São Francisco de Paula durante o 7 de Setembro. ${ }^{11}$ No dia seguinte, mais um missivista, Hum que não está prompto para tudo, cobrava das autoridades uma definição sobre a tal denúncia, pois "a ser ilusão, ou espírito de maledicência, devia fazer recair sobre seu ousado autor a punição, que a Lei marca aos amotinadores, e atiçadores de discórdias públicas". ${ }^{12}$

Malgrado os temores, a celebração da Independência transcorreu sem que os terríveis prognósticos se confirmassem. ${ }^{13}$ Entrando na polêmica, O Exaltado, redigido pelo padre Marcelino Ribeiro Duarte, atacou duramente o autor da denúncia, vista como mais uma manobra dos moderados, visando espalhar o terror e a consternação entre a população para melhor manipulá-la e justificar a perseguição aos exaltados, usados como bode expiatório. ${ }^{14}$ Ainda no dia 10, o Diario do Rio de Janeiro publicava outra carta do criador da polêmica, desta vez assinando $O$ que ainda está pronto para tudo, na qual reiterava seu alerta e afirmava que fora o responsável pelo recuo dos "rusguentos assassinos":

Os anarquistas desesperaram-se de ver descobertos e malogrados seus infames projetos. Alguns prudentes arrepiaram-se, duvidando de que aquela gente ainda pretenda alçar o colo à vista da energia do Governo (...) só o zelo por a tranqüiladade $[s i c]$ Pública me levou a publicar aquele anúncio, para dispertar os bons Brasileiros, e fazer conhecer ao Governo o apoio com que deve contar. ${ }^{15}$

Toda essa polêmica revela a que ponto chegavam as animosidades e a ansiedade coletivas na Corte, indicando o estado de mobilização e alerta da

\footnotetext{
${ }^{10}$ Ibidem, no 5 , de 6/9/1831.

${ }^{11}$ Ibidem.

${ }^{12}$ Ibidem, no 6, de 7/9/1831.

${ }^{13}$ Ocorreu apenas uma pequena confusão no teatro São Pedro de Alcantara, devido a manifestações turbulentas da platéia exaltada e a uma agressão de um brasileiro a um português. Cf. Astréa, no 746, de 17/9/1831.

${ }^{14}$ O Exaltado, n ${ }^{\circ} 5$, de 10/9/1831.

${ }^{15}$ Diario do Rio de Janeiro, no 8, de 10/9/1831.
} 
população; também demonstra que não só os exaltados estavam dispostos a inflamar a opinião pública e chegar às últimas conseqüências para fazer valer suas crenças políticas. Por outro lado, é significativo que nenhuma declaração de apoio à carta polêmica tenha surgido da parte dos moderados, temendo, talvez, alguma tragédia em um conflito aberto.

Mas, na noite de 25 de setembro, por volta das dez e meia, desceram do morro do Nheco (Santa Teresa) mais de trinta amotinadores, "a mor parte muito mal vestidos e alguns descalços" (decerto, cativos), que arrombaram a casa de um comandante de esquadra da Guarda Municipal, pegaram as armas e atacaram duas rondas na Cidade Nova. No caminho, pararam em frente à casa do major Miguel de Frias e Vasconcellos, "dando-lhe vivas, e intitulando-o o General". Reforçados por várias adesões, chegaram em grupo de cinqüenta a sessenta pessoas aos quartéis do campo da Honra (praça da República), onde, dos portões, exortaram os soldados a acompanhá-los. Sendo estes contidos pelos oficiais, o bando decidiu ir embora, após dar "vivas à Constituinte, à República, morras aos chumbos, ao ministro da Justiça e soltado gritos de - abaixo a Regência, fora os Deputados, \& c.”. Na retirada, os guardas municipais, reunidos na Cidade Nova em número superior a oitenta, agarraram seis ou sete amotinadores, que, contudo, foram logo resgatados por seus companheiros, com auxílio de uma ronda que se juntara ao grupo. Este ainda teria recebido a ajuda de um delegado da paróquia de Santa Anna e de um comandante de esquadra. Todavia, com a mobilização dos guardas municipais das demais freguesias, os asseclas do "partido rusguento" dispersaram-se, impunemente, já em torno de uma hora da manhã. ${ }^{16}$

Era o prenúncio do que aconteceria três dias depois, no teatro São Pedro de Alcantara. Ponto habitual de reunião dos exaltados, o local era foco de agitação política e, não raro, palco de pequenos tumultos. Contudo, na noite de 28 de setembro, o conflito atingiu maiores proporções, para o que deve ter colaborado a libertação recente de vários indivíduos implicados na sedição de julho. ${ }^{17}$ Estava em cena o drama $O$ estatutário, em benefício do ator Manoel Baptista Lisboa. Às dez horas, o juiz de paz do Sacramento, Saturnino de

\footnotetext{
${ }^{16}$ Aurora Fluminense, ${ }^{\circ}$ 536, de 28/9/1831.

${ }^{17}$ A descrição a seguir baseia-se, fundamentalmente, em Saturnino de Souza e Oliveira, Relatorio do Juiz de Paz da Freguezia do Sacramento, dirigido ao Ministro da Justiça, sobre os acontecimentos da noite de 28 de Setembro de 1831 no Theatro, [Rio de Janeiro], Typographia Imperial e Constitucional d'Emile Seignot-Plancher, [1831]. 2 p. O relatório também foi publicado no Jornal do Commercio, no 26, de 3/10/1831; e no Diario do Rio de Janeiro, no 3, de 4/10/1831. As partes citadas nesta descrição foram todas extraídas deste documento.
} 
Souza e Oliveira, responsável pela segurança do espetáculo, foi chamado em seu camarote para conter uma briga fora do teatro, entre o tenente Antonio Caetano e o oficial do Estado-Maior do Exército F. Paiva. Este acusava aquele de tê-lo atacado, com mais seis pessoas, e arrancado sua espada, enquanto o primeiro dizia que o segundo é que o atacara com espada.

O juiz de paz deu ordem de prisão a ambos, mas Antonio Caetano, alegando ser oficial, recusou-se a ser conduzido pela patrulha, só aceitando acompanhar, preso, o comandante da guarda do teatro até a Guarda Principal. Foi o bastante para que "um grupo de Povo" começasse a gritar que Antonio Caetano, brasileiro nato, não iria preso e o puxasse para a multidão. Em meio à confusão, o oficial Paiva, brasileiro adotivo, desapareceu (soube-se depois que se recolhera à Guarda Principal), o que atiçou mais os ânimos; gritavam os "amotinadores" que o juiz de paz "havia soltado o Chumbo, e queria prender ao Brasileiro". Este foi levado para a platéia do teatro por um grupo liderado pelo alferes do $5^{\circ}$ Batalhão de Caçadores, Francisco Bacellar. Lá, Caetano começou a "gritar que estava preso por causa de um Chumbo que o atacou, mas que este fora solto, e que estávamos traídos", gerando grande alarido. O juiz de paz deu-lhe nova ordem de prisão, à qual se opôs, com ajuda do tenente Leopoldo (Frederico Thompson, também do $5^{\circ}$ Batalhão), ${ }^{18}$ o major Miguel de Frias, que se achava vestido, à moda exaltada, de sobrecasaca e chapéu de palha, ${ }^{19}$ ambos alegaram ao juiz de paz que não haveria prisão porque "a populaça não queria, e esta podia mais do que eu".

A esta altura, segundo o juiz de paz, já estavam reunidos em volta do teatro mais de duzentos guardas municipais. Isto, porém, não intimidou os manifestantes, que ficaram ainda mais agressivos e numerosos, passando a assobiar e a "provocar as Guardas com os maiores insultos, e palavras obscenas". O juiz de paz mandou, então, fechar o teatro e ordenou a quatro guardas municipais que prendessem os primeiros que saíssem do saguão em atitude provocativa. Logo vieram quatro indivíduos, "à testa dos quais estava um pardo escuro com um cacete na mão" e, assim que os guardas municipais os abordaram, ainda no saguão, foram estes agredidos e suas armas arrancadas. Na confusão, um tiro foi disparado para fora por um dos manifestantes, precipitando a

\footnotetext{
${ }^{18}$ Bacellar e Leopoldo foram signatários, em julho, de uma representação de seu batalhão, condenando a revolta e dando apoio ao governo. O primeiro também se destacou, integrando o grupo dos brasileiros, nas Noites das Garrafadas, em março do mesmo ano, assim como o alferes José Alexandre, referido adiante.

${ }^{19} \mathrm{O}$ detalhe consta da carta de Saturnino Oliveira, publicada na Aurora Fluminense, $\mathrm{n}^{\circ} 541$, de 10/10/1831.
} 
reação dos guardas municipais postados em volta do teatro, que prontamente "começaram também a fazer fogo desconcertadamente, disparando para mais de 30 tiros", apesar dos apelos do juiz de paz e do comandante-geral da Guarda Municipal do Sacramento para suspenderem o fogo. Quando este finalmente cessou, havia três indivíduos mortos e dois feridos, além de "alguns mui poucos dos Guardas Municipais". ${ }^{20}$ Após o tiroteio, a multidão se dispersou, mas continuaram a chegar à praça da Constituição guardas convocados de várias freguesias, de modo que, à meia-noite, se achavam reunidos no local mais de 1.400 guardas e, em toda a cidade, mais de 3 mil, só dispensados às quatro horas da manhã. ${ }^{21}$

Segundo a Aurora Fluminense e O Independente - jornais moderados, escritos, respectivamente, por Evaristo da Veiga e Joaquim José Rodrigues Torres -, um grupo de revoltosos dirigiu-se, ainda de madrugada, ao quartel do $5^{\circ}$ Batalhão, procurando sublevá-lo; ${ }^{22}$ de acordo com o último periódico, eram cerca de cem pessoas e, com o primeiro, quarenta ou cinqüenta, as quais, unidas aos soldados e lideradas pelo alferes Bacellar, perseguiram várias rondas municipais. ${ }^{23} \mathrm{O}$ fato é confirmado por duas cartas publicadas no Diario do Rio de Janeiro. Em uma delas, Hum dos 35 insultados reclamava que a esquadra de guardas municipais a que pertencia, formada por 35 homens, fora atacada na madrugada do dia 29, na rua dos Barbonos (Evaristo da Veiga), por cerca de setenta exaltados, entre civis e militares do $5^{\circ}$ Batalhão, que teriam atirado contra os milicianos, desarmando-os e prendendo-os. ${ }^{24} \mathrm{O}$ mesmo episódio, narrado com mais detalhes, foi relatado por Hum Verdadeiro Brasileiro. Segundo este, o grupo de exaltados, comandado por "um Oficial Rego, vindo com este à frente mais dois, Bacellar, e José Alexandre”, teria abordado sua esquadra da Guarda Municipal e perguntado ao comandante se todos ali eram brasileiros. Diante da resposta positiva, intimou os guardas a se unirem àquele grupo e marcharem juntos para a praça da Constituição, ameaçando atacar os

${ }^{20}$ Um dos mortos foi o guarda-marinha Manoel José de Araujo, que, segundo O Clarim da Liberdade ( $\mathrm{n}^{\circ} 8$, de 10/12/1831), era patriota pernambucano, filho do negociante e coronel de milícias Alexandre José de Araujo, vítima da repressão à Confederação do Equador; estudou em Coimbra, mas não se formou por falta de recursos.

${ }^{21} \mathrm{O}$ relatório do juiz de paz - escrito para dar satisfações à Regência apenas dos fatos sucedidos sob sua responsabilidade - termina neste ponto, sem abordar as ações subseqüentes. O mesmo fez a imprensa exaltada. Somente as folhas moderadas narraram os distúrbios do dia 29, visando alarmar a população contra os exaltados.

${ }^{22} \mathrm{O} 5^{\circ}$ Batalhão esteve envolvido na revolta de julho, mas, na ocasião, protestou fidelidade ao governo.

${ }^{23}$ O Independente, $\mathrm{n}^{\circ} 44$, de 30/9/1831; e Aurora Fluminense, ${ }^{\circ}$ 538, de 3/10/1831.

${ }^{24}$ Diario de Janeiro, ${ }^{\circ}$ 6, de 7/10/1831. 
recalcitrantes. Enquanto o comandante da guarda esforçava-se por acalmar os ânimos, quatro milicianos tentaram escapar, no que foram prontamente impedidos por alguns exaltados, que prepararam as baionetas e "lhes dispararam um tiro", desarmando e prendendo, em seguida, os demais, levados para o quartel dos Barbonos. Embora louvasse a bravura dos guardas, o missivista reconhecia que alguns tinham "logo em princípio da questão se passado para o Corpo de Tropa". ${ }^{25}$

Ao amanhecer, "Grupos de negros, e pardos da ínfima classe, rotos, e meio descalços se espalharam por várias ruas da cidade, armados de porretes e facas", assassinando três cidadãos e espancando ou ferindo vários taberneiros. Contudo, logo chegou a Guarda Municipal e dispersou os "anarquistas", prendendo alguns. Malogrou também a tentativa de realizar um ajuntamento na praça da Constituição, "a titulo de lastimarem o sangue Brasileiro vertido". À noite, reuniram-se os manifestantes em frente ao quartel do $5^{\circ}$ Batalhão, na rua dos Barbonos, aguardando a chegada, segundo boatos que varriam a cidade, dos soldados do $3^{\circ}$ Batalhão e do Corpo de Artilharia da Marinha; ${ }^{26}$ diziam contar, ainda, com o apoio de "um grosso de paisanos comandados pelo Padre M..... ${ }^{27}$ Mais uma vez, porém, a Guarda Municipal interveio, cercando o quartel com duzentos guardas de Cavalaria e outros tantos de Infantaria. Dos cerca de setenta rebeldes "de todas as classes" que ali estavam, foram presos "para mais de trinta", conforme a Aurora Fluminense, e "uns nove ou dez", segundo $O$ Independente. ${ }^{28}$ Além disto, tomaram-se as providências cautelares necessárias para impedir que os soldados da Artilharia da Marinha, situados na Ilha das Cobras, pudessem desembarcar, caso tentassem. As patrulhas municipais permaneceram mobilizadas na rua até o início da madrugada, quando a ordem foi restabelecida.

No dia $1^{\circ}$ de outubro, o juiz de paz do Sacramento fez uma proclamação aos guardas municipais da freguesia, agradecendo e elogiando a conduta prudente na noite de 28; "insultados, e provocados ao último ponto", ainda quando se viram obrigados a reagir, deram a maior parte dos tiros para o ar. Criticava, porém, a atitude da guarda militar postada em frente ao teatro, que "não só não me tinha coadjuvado para sustentar a ordem, e mostrava-se indiferente

\footnotetext{
${ }^{25}$ Ibidem, n ${ }^{\circ} 8$, de 11/10/1831.

${ }^{26}$ Ao menos quanto à Artilharia de Marinha, tais rumores tinham sua razão de ser, pois, uma semana depois, era a vez de esta unidade se rebelar, na Ilha das Cobras.

${ }^{27}$ Aurora Fluminense, $\mathrm{n}^{\circ}$ 538, de 3/10/1831. Trata-se, decerto, do padre Marcelino, redator d'O Exaltado.

${ }^{28}$ Ibidem; e O Independente, $\mathrm{n}^{\circ} 44$, de 30/9/1831.
} 
expectadora dos ultrajes, que se nos faziam, mas até se nos mostrara hostil, calando baionetas ao primeiro reforço, que chegou à entrada do saguão", o que poderia acarretar a perda de muitas vidas naquele espaço exíguo. ${ }^{29}$ Seguiramse diversas outras proclamações, como a do comandante da $5^{\text {a }}$ esquadra da freguesia de São José, João José Pereira, aos guardas municipais sob seu comando, e a do juiz de paz suplente da freguesia do Engenho Velho, Felix José da Silva, ao comandante-geral, aos comandantes de esquadra, aos delegados e aos guardas municipais da mesma freguesia, louvando a prontidão com que estes se apresentaram na manhã do dia 29, "por estar a Cidade em desassocego motivado por grupos de mais de 200 pessoas, a maior parte malfeitores". ${ }^{30}$ O mesmo fez a Sociedade Defensora, em ofício ao juiz de paz do Sacramento (sócio da entidade), parabenizando-o pelos "esforços, que fizestes para poupar o sangue daqueles mesmos, que cegos de seu frenético furor não cessavam de cobrir-vos de injúrias". ${ }^{31}$ Em 6 de outubro, a mesma sociedade enviou circular às associações provinciais, relatando, sob a ótica do governo, os distúrbios de 25, 28 e 29 de setembro, atribuídos ao "frenético delírio de homens, que em nome da liberdade se julgam com direito de cometer todos os desatinos". 32

Sob o impacto desses acontecimentos, em 3 de outubro o Senado enviou à Câmara dos Deputados proposta de criação de um Corpo de Guardas Municipais voluntário, para "manter a tranqüilidade pública, e auxiliar a Justiça”, e a Assembléia Geral decretou uma série de medidas judiciais vigorosas, no intuito de desencorajar outros possíveis distúrbios. ${ }^{33}$ Ainda assim, Feijó, em ofício de 6 de outubro à Câmara dos Deputados (já sob o novo impacto da sedição da Ilha das Cobras), a pretexto de uma consulta que esta lhe fizera a respeito da observância do Código Criminal para os implicados nos acontecimentos do Teatro, ${ }^{34}$ queixou-se de que "a insuficiência das Leis

\footnotetext{
${ }^{29} \mathrm{Ver}$ O Independente, ${ }^{\circ} 45$, de 4/10/1831; e Diario do Rio de Janeiro, $\mathrm{n}^{\circ} 3$, de 4/10/1831.

${ }^{30}$ Cf. Diario do Rio de Janeiro, no 4, de 5/10/1831.

${ }^{31}$ Cf. O Independente, $\mathrm{n}^{\circ} 46$, de $7 / 10 / 1831$.

${ }^{32}$ Cf. ibidem, $\mathrm{n}^{\circ}$ 52, de 28/10/1831.

${ }^{33}$ As medidas estabeleciam que "se procederá ex-Ofício à inquirição judicial sem tempo determinado, nem número certo de testemunhas" nos casos de conspiração, rebelião, sedição e insurreição, e elevavam as penas dadas a vadios, a portadores de armas perfurantes ou de fogo, aos que proferissem calúnias, injúrias ou resistissem aos juízes de paz e guardas, aos que ferissem ou agredissem fisicamente qualquer autoridade ou particular e aos pronunciados por qualquer crime. Cf. Jornal do Commercio, nos 27, de 4/10/1831, e 28, de 5/10/1831.

${ }^{34}$ Cf. Annaes do Parlamento Brazileiro - Camara dos Srs. Deputados, sessão de 1831, coligidos por Antonio Pereira Pinto, Rio de Janeiro, Typographia de H. J. Pinto, 1878, t. $2^{\circ}$, p. 218 (sessão de 4 de outubro). Os Anais não registram qualquer debate na Câmara acerca dos incidentes de 28 e 29 de setembro.
} 
Criminais, e a falta delas para muitos casos, é a causa dos males que sofre a Capital, e todo o Império". Pleiteando a criação de leis criminais mais enérgicas e mesmo insinuando a necessidade de adoção de iniciativas extraordinárias por parte do Executivo, Feijó declarou que

(...) a liberdade de injuriar, caluniar, e ameaçar desde o primeiro Cidadão até o último: a dificuldade de procurarem-se semelhantes delitos: a má organização dos Jurados, e da Lei, que pune os abusos de exprimir os pensamentos: e o apoio que os perversos têm encontrado em pessoas que mais os deviam censurar em razão do cargo que ocupam, vai introduzindo a imoralidade a ponto tal, que as Leis são inteiramente desprezadas, e as Autoridades vilipendiadas.

Pairava assim, segundo o ministro, ameaça de dissolução do estado social. $^{35}$

Em 30 de setembro, o juiz de paz de São José, João Silveira do Pillar (sócio da Sociedade Defensora), efetuou o corpo de delito indireto, ${ }^{36}$ com base nas partes dadas pelos comandantes de esquadra e de patrulha da Guarda Municipal aos seus superiores e nos depoimentos das testemunhas inquiridas. Quanto às partes, o comandante da esquadra n ${ }^{\circ} 13$, Candido Martins dos Santos Vianna Filho, relatou que, passava das onze e meia da noite quando, em virtude do pequeno número de homens disponíveis, reuniu sua esquadra à da rua das Mangueiras e a uma patrulha da rua de Matta-Cavallos (Riachuelo), formando, no máximo, 35 guardas. Em seguida, contou a mesma história narrada pelos guardas municipais, que escreveram para o Diario do Rio de Janeiro com os pseudônimos de Hum Verdadeiro Brasileiro e Hum dos 35 insultados, acrescentando pequenos detalhes, como as informações de que eram mais de setenta os rebeldes do $5^{\circ}$ Batalhão de Caçadores que os abordaram, e de que lhe foi dito pelo comandante do grupo que a Artilharia da Marinha em breve iria aderir à revolta, além de identificar "um bem conhecido Bacellar", José Alexandre (que pertencera ao Corpo de Polícia), o alferes Rego e um irmão de Bacellar entre os líderes do motim. ${ }^{37}$ Confirmaram

\footnotetext{
${ }^{35}$ Cf. Jornal do Commercio, n ${ }^{\circ} 34$, de 12/10/1831.

${ }^{36}$ Equivalente ao inquérito policial de hoje.

${ }^{37}$ Os autos do corpo de delito indireto encontram-se anexados (p. 4-37) ao Summario que mandou procedero Desembargador José Maria Monteiro de Barros, Juiz do Crime do Bairro de São José sobre Crimes de Sedição, d'arrogar-se, e effectivamente exercer sem direito ou motivo legitimo Comando Militar na conformidade do artigo cento quarenta e um do Codigo Criminal, e pela retirada d'armas do poder das Guardas Municipaes. 1831. Sedição militar de 28 de setembro de 1831, Rio de Janeiro, 1831, 67 p., B. N. - D. Mss. 22, 1, 14. As partes dadas por Candido Vianna Filho estão nas páginas 6 a 11 (citação à p. 6).
} 
a versão os comandantes da patrulha e da esquadra referidos - João Baptista Montaury e Cyrillo Antonio Machado; este, reconhecendo o alferes Bacellar como um dos cabeças, e aquele, afirmando que gritaram para ele: "mata que é Chumbo", e o forçaram entregar pistolas e munição. ${ }^{38}$ Já o comandante de patrulha, Antonio Camillo Dias, relatou também a coerção feita por paisanos e militares do $5^{\circ}$ Batalhão, acrescentando que as armas tiradas dos guardas foram entregues aos civis do grupo e que muitos daqueles acompanharam livremente os rebeldes até o quartel. ${ }^{39}$

O juiz de paz ouviu seis testemunhas, todas guardas municipais. A primeira, o mestre carpinteiro Florianno da Rocha, homem branco, 45 anos, casado, natural do Rio de Janeiro e morador da rua das Marrecas, participara da ronda da rua dos Barbonos; após ouvir as partes dos comandantes, confirmou todos os relatos, em particular o de Candido Vianna Filho, afirmando ainda reconhecer os alferes Bacellar e Rego entre os líderes das mais de 30 manifestantes que abordaram sua patrulha. ${ }^{40} \mathrm{~A}$ segunda testemunha, o estudante Vasco Fernandes de Moraes, branco, solteiro, 21 anos, nascido no Rio de Janeiro, morador do largo da Lapa e também integrante da ronda dos Barbonos, só acrescentou que, além de Rego, José Alexandre, Bacellar e o irmão deste, reconhecera também o oficial ou cadete Gualdino de tal Valladares. ${ }^{41}$ A terceira, o guarda-mor da Alfândega Marcos Antonio de Azevedo Coutinho Montauri (provavelmente parente do comandante de mesmo sobrenome), branco, solteiro, 21 anos, fluminense e morador do largo do Paço (praça Quinze de Novembro), igualmente repetiu relatos anteriores, inclusive que os rebeldes esperavam a adesão da Artilharia da Marinha e gritaram para seu pequeno grupo (três pessoas) de Cavalaria: "mata que [é] Chumbo"; mas só identificou José Alexandre. ${ }^{42}$ A quarta foi Candido Martins dos Santos Vianna Filho (com isto, ficamos sabendo que era branco, casado, 31 anos, escrivão do Juízo de Órfãos e morador da rua das Marrecas), que rei-

\footnotetext{
${ }^{38}$ Ibidem, p. 12-14 (citação, p. 14). O comandante da esquadra de Montaury, José Dias da Cruz Lima, apenas se remeteu à parte dada por seu subordinado (p. 14-15). O mesmo fez o comandante da esquadra $\mathrm{n}^{\circ} 10$, Joaquim Teixeira de Macedo, em relação à parte de Antonio Camillo Dias, complementando que muitos dos guardas sob seu comando se negaram a rondar no dia 29, alegando que os rebeldes roubaram suas armas (p. 16).

${ }^{39}$ Ibidem, p. 17-19. A parte é assinada também pelos guardas municipais José Silvestre Rebello, Antonio Jacinto Chaves, José Machado d'Oliveira, João Rodrigues di Proença, Ivo José dos Santos, Duarte José do Carmo, Manoel Gonçalves Pires e Joaquim Maria da Costa Mattos.

${ }^{40}$ Ibidem, p. 19-21.

${ }^{41}$ Ibidem, p. 21-23.

42 Ibidem, p. 24-26 (citação à p. 25).
} 
terou tudo o que disse nas partes dadas a seu superior, esclarecendo apenas que, dos cerca de setenta homens que abordaram sua esquadra, pelo menos trinta eram do $5^{\circ}$ Batalhão, sendo de paisanos o restante; e que os oficiais do dito tentaram e conseguiram aliciar alguns guardas. ${ }^{43} \mathrm{O}$ quinto depoente foi o então desembargador da Suplicação (e já deputado geral, futuro presidente de província, ministro, conselheiro de Estado, senador e Marquês do Paraná) Honorio Hermeto Carneiro Leão, branco, casado, 30 anos e morador da rua das Marrecas, de cuja esquadra fazia parte, e que, relatando a mesma história contada pelos demais, declarou que o oficial Rego (auxiliado por Bacellar) primeiro interpelou se todos ali eram brasileiros, bradando, neste caso, que deveriam se juntar ao seu grupo ou então enfrentá-lo, e depois dissera que "naquela noite se havia praticado um ato muito pior do que o da Praça do Commercio, e que eram precisos [sic] marchar para de uma vez ficarmos livres"; informou ainda que alguns guardas da retaguarda - ele inclusive - lograram escapar em meio à discussão em que os manifestantes tentavam convencer ou forçar os municipais a acompanhá-los. ${ }^{44} \mathrm{O}$ último a depor, o sargento-mor e comissário pagador da Tesouraria das tropas da Corte José Maria Lopes da Costa - branco, casado, 30 anos, também morador da rua das Marrecas e integrante da guarda da rua dos Barbonos - prestou as mesmas informações que os outros; porém acrescentou que a força rebelde (comandada por Rego, Bacellar e José Alexandre) tinha de setenta a oitenta pessoas, das quais trinta a quarenta do $5^{\circ}$ Batalhão e as demais eram paisanos, e que a mesma pretendia ir para o Rossio (praça da Constituição). ${ }^{45}$

Em $1^{\circ}$ de outubro, o juiz de paz Pillar julgou procedente o corpo de delito indireto e passou os autos ao juiz do crime do bairro de São José, desembargador José Maria Monteiro de Barros (também sócio da Defensora). Este, no dia 4, instaurou o sumário (formação de culpa) para os crimes de "Sedição, d'arrogar-se, e efetivamente exercer sem direito ou motivação legítima o Comando Militar", conforme o artigo 141 do Código Criminal, e de "tirada das Armas do poder dos Guardas Municipais".

Dez testemunhas participaram da inquirição, das quais seis deram depoimento na etapa anterior: Carneiro Leão, Candido Vianna Filho, Vasco Fernandes de Moraes, Marcos Montauri, Florianno da Rocha e José Maria da Costa, que, salvo pequenos detalhes, repetiram integralmente o que falaram

\footnotetext{
${ }^{43}$ Ibidem, p. 26-29.

${ }^{44}$ Ibidem, p. 30-34 (citação à p. 32).

${ }^{45}$ Ibidem, p. 34-36.
} 
no corpo de delito indireto. ${ }^{46}$ Foi também convocado o fundidor português Antonio Camillo Dias, branco, solteiro, 23 anos, morador da rua de MattaCavallos, cuja patrulha comandava, e que fez um relato mais amplo do que a parte dada ao seu superior, embora pouco acrescentasse aos depoimentos de seus colegas; de novidade, só a observação de que o alferes Rego teria dito que "no Teatro se estavam matando os nossos Compatriotas, e que naquela mesma noite haviam de ser vingados", e que somente ele e o conselheiro José Silvestre não aderiram à debandada geral da força municipal que integravam, mas foram logo desarmados por Bacellar. ${ }^{47}$ Uma das novas testemunhas foi justamente o conselheiro português José Silvestre Rabello, homem branco, solteiro, 55 anos, também morador de Matta-Cavallos, que adicionou ao dito pelas demais que, após intimidar os guardas, os revoltosos deixaram sua ronda seguir em serviço, aparecendo uma hora depois um oficial do Estado Maior do Exército a caminho do quartel do $5^{\circ}$ Batalhão, afirmando que faria com que os rebeldes se recolhessem; por volta das duas da manhã, veio do quartel o cadete Ferraz, dizendo que os soldados estavam deitados junto à porta e os oficiais, já um tanto arrependidos, sentados ao lado de uma tarimba de aguardente, distribuída com pipoca e amendoim..$^{48}$ Outra nova testemunha (a única que não esteve no palco da ação), o tenente-coronel Manoel José de Castro, branco, casado, quarenta anos, nascido em Portugal e morador da rua da Ajuda, disse que, sendo informado em sua casa do distúrbio (onde se achava doente), ordenou que nenhum soldado saísse do quartel e nem entrasse ali qualquer paisano; mas, sabendo depois que a ordem não fora cumprida, só não fora ao encontro dos soldados porque estes já se haviam recolhido em sossego no quartel..$^{49}$ Por fim, Antonio Jacinto Chaves Pereira Ferraz, branco, solteiro, vinte e oito anos, natural do Piauí, que vivia de seu soldo (de cadete), informou que fazia parte da ronda de Matta-Cavallos e confirmou o que a seu respeito dissera o conselheiro Rabello (sobre a embriaguez que observara no quartel), além de apontar Rego e os irmãos Bacellar como chefes dos manifestantes. ${ }^{50}$

${ }^{46}$ Ibidem, p. 38-49, 58-59 e 62-65. Entre os acréscimos, Montauri declarou que os revoltosos lhe teriam dito: "mata que é do partido do Saturnino e que é Chumbo" e que só não o mataram porque queriam que ele buscasse a Cavalaria para se unir ao grupo e, assim, soltando-o (p. 48-49). Há também a informação de Vianna Filho identificando José Antonio, Florianno da Costa, Jacinto Ferreira de Paiva, Antonio José da Costa e Bernardo de tal entre os guardas de sua esquadra que não fugiram, ao serem abordados pelos rebeldes (p. 44).

${ }^{47}$ Ibidem, p. 53-56 (citação à p. 55).

${ }^{48}$ Ibidem, p. 49-53.

${ }^{49}$ Ibidem, p. 56-58.

${ }^{50}$ Ibidem, p. 60-62. 
Finalmente, em 8 de outubro (já sob impacto do levante da Ilha das Cobras), o juiz do crime José Maria Monteiro de Barros pronunciou a prisão dos alferes do $5^{\circ}$ Batalhão de Caçadores, Francisco Joaquim Bacellar e João do Rego Marques; o alferes do extinto Corpo Militar de Polícia, José Alexandre; e o tenente do também extinto $2^{\circ}$ Batalhão, Antonio Joaquim Bacellar, de fato apontados em todos os depoimentos como líderes dos rebeldes. ${ }^{51}$ Como a devassa só diz respeito ao ocorrido logo após o incidente do teatro, não menciona outros implicados, como o major Miguel de Frias e Vasconcellos, o $2^{\circ}$ tenente Honorio José Ferreira (ambos do Corpo de Engenheiros) e o tenente Leopoldo Frederico Thompson (do $5^{\circ}$ Batalhão), todos presos, como os primeiros, nas fortalezas de Santa Cruz, São João, Villegaignon e Lage. ${ }^{52}$

Pelo menos dois destes entraram com recurso, pedindo revisão de processo. Em seu requerimento, Miguel de Frias - pronunciado pelo juiz do crime do bairro do Sacramento por resistência e tirada de presos do poder da Justiça, durante a confusão do teatro - alegou, a respeito do primeiro delito (que o levou a perder o foro militar de julgamento), que não resistiu à Justiça e que nem havia configuração legal do crime, uma vez que o juiz de paz não lavrara o auto de resistência, como determinava a lei. Quanto ao segundo delito, argumentou que o próprio juiz de paz Saturnino admitia, em seu relatório, que o acusado dissera na ocasião que iria responder pelo preso Antonio Caetano, prerrogativa a que teria direito na qualidade de oficial militar. Além disto, completava, nenhuma das trinta testemunhas ouvidas o incriminara. Assim, concluía o agravo, ponderando:

Embora nos achemos em uma época, em que todos se consideram Jurisconsultos, (...) suas doutrinas devem ficar nas Folhas, que as publicam, e quando muito, nas praças, e lojas, em que se lêem, e pregam: nunca devem traspassar esses limites, e ainda menos tomar assento nas mesas dos Tribunais de Justiça. ${ }^{53}$

Outro a recorrer foi Honorio Ferreira, que não chegou a ser pronunciado, mas foi preso por decisão do Conselho de Guerra e, em 19 de novembro, teve negado seu pedido de habeas corpus, o que o levou a apelar para a Regência contra a medida inconstitucional e arbitrária, acusando o ministro da Guerra de

\footnotetext{
${ }^{51}$ Ibidem, p. 65.

${ }^{52}$ Jornal do Commercio, no 25, de 1/10/1831; e Manuel Duarte Moreira de Azevedo, op. cit., p. 356-357.

${ }_{53}$ Miguel de Frias e Vasconcellos [Requerimento a S. M. I. e C.pedindo a subida do processo de devassa com sua petição], Rio de Janeiro, Typographia Nacional, 1832 (provavelmente março), citação à p. 10.
} 
estar assim incurso na lei de responsabilidade dos ministros e dos conselheiros de Estado. Em sua versão - se preciso atestada por testemunhas, dizia - alegou que não tivera qualquer participação no distúrbio do teatro, tendo apenas ido à ópera, como de costume, e já se achava, no começo da confusão, na rua do Piolho (Carioca), recolhendo-se depois à sua casa. ${ }^{54}$

Como de hábito, a imprensa moderada aproveitou a ação malograda dos exaltados para estigmatizá-los como anarquistas e, em seu relato, reproduziu a versão oficial manifesta no relatório de Saturnino Oliveira. Defendendo a conduta do juiz de paz, a Aurora Fluminense e O Independente focaram os pontos mais polêmicos do cerco e da evacuação do teatro, e do tiroteio promovido pelos guardas municipais. O problema consistia em saber, de um lado, se as portas do teatro estavam ou não abertas à platéia que assistia ao espetáculo e, de outro, se houve ou não imprudência nos tiros dados pelos guardas, se foram dados para o alto, a esmo ou em direção ao público. Assim, a Aurora Fluminense sustentava que as portas estavam abertas para quem quisesse sair e que os "primeiros tiros foram dados da parte dos amotinadores, e depois de haverem vomitado contra os guardas municipais toda a sorte de insultos e de convícios: o fogo que estes fizeram foi em defesa natural contra a agressão". ${ }_{55}$

Ambos os jornais acusavam as folhas exaltadas de distorcerem os fatos por espírito de partido: "o número dos mortos foi elevado a mais de vinte, várias circunstâncias inverossímeis acrescentadas para tornar odiosa a Guarda de cidadãos (...) só para incendiarem ânimos inexpertos". Para a Aurora Fluminense, os distúrbios foram obra dos "soldados da Nova Lus", que continuavam a iludir as pessoas com os "doces nomes de pátria, de liberdade, cujo sentido a perversidade dos agitadores inverte" ${ }^{56} \mathrm{O}$ mesmo dizia $O$ Independente, garantindo que sua narrativa dos acontecimentos era atestada pelo relatório do juiz de paz e por testemunhos fidedignos, bem diferente da "maneira por que os têm já invertido a N. Luะ, Jurujuba \&". ${ }^{57}$

Por sua vez, as folhas exaltadas viam os distúrbios como uma trama moderada, um atentado à liberdade, típico de um governo tirânico. A Nova Luะ Brasileira acusava Saturnino de promover de propósito um massacre, pois, "quando o Povo, e famílias, que ali se achavam, quiseram sair, acharam o Teatro circulado por Guardas Municipais compostas na maior parte, dos bons

\footnotetext{
${ }^{54}$ Cf. O Clarim da Liberdade, $\mathrm{n}^{\text {os }} 6$, de 3/12/1831, e 10, de 17/12/1831.

${ }^{55}$ Aurora Fluminense, ${ }^{\circ} 538$, de 3/10/1831.

${ }^{56}$ Ibidem.

${ }^{57}$ O Independente, ${ }^{\circ}$ 45, de 4/10/1831.
} 
Capitalistas de Março, e as portas todas tomadas, proibindo-se a saída". Inversa também era a visão sobre o tiroteio na entrada do teatro: tudo começara quando o jovem brasileiro Araujo reclamou da interdição das saídas, chamando isso de traição, e deu vivas à liberdade e independência do Império.

Foi ao proferir nomes tão sagrados que um dos da ronda lhe tirou a vida com um tiro de bala; e foi nesse mesmo momento que à imitação da Praça do Commercio estes vândalos de fardeta, e boné (...) fizeram fogo para dentro do Teatro pelas portas da frente, e óculos laterais. ${ }^{58}$

Contrariando o cálculo do juiz de paz de três mortos e dois feridos no tiroteio (sem contar os guardas municipais), o jornal assegurava que o saldo era de cinco mortos (inclusive uma senhora) e muitos feridos, vítimas inocentes dos tiros indiscriminados dados pelos guardas municipais. Buscava, assim, estabelecer uma linha de continuidade - dada pelo caráter despótico - entre os governos de Pedro I e da Regência:

Brasileiros! Pedro 1 assinalou o começo do seu governo com o massacre horrendo da Praça do Commercio: os malvados jesuítas moderados assinalaram o começo do Governo de Pedro 2 com o massacre horrendo do Teatro na noite de 28 de Setembro! Refleti, e obrai.

Todavia, tal como os publicistas das folhas moderadas, o redator admitia não ter testemunhado os fatos; "mas é o que ouvimos a todos, mesmo àqueles que têm interesse em desfigurar este fato horrendo". 59

Para $O$ Exaltado também o episódio do teatro foi "o maior dos atentados, o fato mais atroz, mais bárbaro, e horroroso, sem semelhante na História da Barbaridade"; uma "traição horrenda", há muito tramada pelos que se dizem moderados, pelos "Conspiradores dos Prontos para tudo", "monstros, sedentos do sangue de seus concidadãos, esses homens sem pátria, sem coração, sem alma". Tratar-se-ia, portanto, de conspiração, visando massacrar os exaltados e justificar uma ulterior perseguição. Sobre a conduta do juiz de paz, o jornal também afirmava que os guardas municipais - todos portugueses - "muito de propósito, para tão monstruoso atentado, dispararam sobre o Povo inerme"

\footnotetext{
$\overline{{ }^{8} \mathrm{O} \text { incidente da praça do Commercio - quando eleitores reunidos em assembléia foram }}$ violentamente reprimidos pelo governo joanino, nos dias 21 e 22 de abril de 1821 - era sempre lembrado pelas folhas exaltadas como exemplo de repressão despótica. Cf. Ruth Maria Kato, "Revoltas de rua: o Rio de Janeiro em três momentos (1821-1828-1831)", Dissertação de Mestrado, Rio de Janeiro, IFCS-UFRJ, 1988, capítulo II, parte 3. Já Capitalistas de Março era referência aos comerciantes portugueses que participaram das Noites das Garrafadas.

${ }^{59}$ Nova Luะ Brasileira, ${ }^{\circ}$ 176, de 29/9/1831.
} 
que tentava sair pela porta da frente e pelas laterais do teatro. $\mathrm{O}$ resultado: muitos mortos e 35 feridos; entre as "vítimas sacrificadas ao Amor da Pátria, e a Liberdade pela Aristocracia Despótica", lamentava a morte do guarda-marinha Araujo, "jovem de grandes esperanças, o autor das poesias oferecidas às Senhoras Brasileiras". Por fim, o jornal (que também admitia estar a par dos fatos por testemunhas oculares) clamava por vingança e prenunciava trágicas conseqüências. ${ }^{60}$

Por sua vez, O Jurujuba dos Farroupilhas, redigido por João Baptista de Queiroz, fazia eco a tais declarações, afirmando que tudo fora premeditado. A prova é que "As padiolas para carregarem os mortos, é voz pública, que estiveram prontas como por encanto; e diz ela que à tarde se prevenira a certos Patriotas do Dia, para que levassem escovadas, e bem prontas as suas armas". Nesta "nova carnificina da Praça do Commercio", comandada por Saturnino, o povo fora impedido de sair do teatro, enquanto os guardas municipais, após atirarem contra os que tentavam se evadir, entraram no saguão de baioneta calada: "metia dó a gritaria das Senhoras Brasileiras encurraladas dentro". Daí resultou o assassinato de sete pessoas, afora os feridos. ${ }^{61}$

Corroborando esta visão, inclusive o paralelo com o episódio da praça do Commercio, a Sentinella da Liberdade, do célebre Cipriano Barata, assinalava que o "massacre no teatro" fora premeditado pela "facção Luso aristocrata" para "dar cabo da Mocidade mais entusiasmada pela Pátria". Os sete mortos seriam um sueco, um português, um cadete de Pernambuco, um menino, uma mulher e dois brasileiros, além da tal senhora, viúva e mãe de cinco filhos, que faleceu depois; sem contar os mais de trinta feridos, alguns gravemente. Mas, seguindo a tática de dramatizar os fatos pelo exagero e pelo apelo emocional, o jornal levantava a suspeita de que o número de óbitos era maior, havendo vítimas sepultadas clandestinamente pelos sequazes do juiz de paz. ${ }^{62}$

Parte da opinião pública participou ativamente do debate sobre os distúrbios, via seção de correspondência dos jornais. Ampla maioria apoiava as medidas tomadas pelas autoridades, adotando a perspectiva e a defesa da

${ }^{60}$ O Exaltado, n ${ }^{\circ}$ 9, de 8/10/1831.

${ }^{61}$ O Jurujuba dos Farroupilhas, n ${ }^{\circ}$ 7, de 30/9/1831 (ver também o n ${ }^{\circ}$ 9, de 6/10/1831).

${ }^{62}$ Sentinella da Liberdade na Guarita do Quartel General de Pirajá: Hoje Preza na Guarita da Ilha das Cobras em o Rio de Janeiro. Alerta!!, n 25, de 15/10/1831. A mesma interpretação encontrase em um panfleto anônimo exaltado, que via o episódio como outra trama dos moderados, "a fim de saciarem suas entranhas sedentas de cobiça a perseguir a tudo quanto era exaltado”. O EXALTADO (pseud.), Visão espantoza, que teve hum Exaltado no morro do Castello e a interpetração [sic] feita por hum Tamoyo, sobre a volta de D. Pedro, Rio de Janeiro, Typographia Fluminense, de Brito e C., s/d. [1832?]. 
ordem e assim reprovando a revolta, atribuída aos exaltados. O guarda municipal Francisco Paula Silva, que atuou no combate aos distúrbios, garantia pegar em armas sempre que preciso para defender "Pedro II, Liberdade, e tranqüilidade pública", e acabar com "meia dúzia de bandalhos anarquistas"; e conclamava à união todos os brasileiros, natos e adotivos, que tivessem a perder "honra, família e bens", pois só "sucumbiremos com pólvora, e bala o montro $[$ sic $]$ da anarquia". ${ }^{63}$ A repressão violenta aos exaltados foi também sugerida ao governo por um missivista anônimo, para quem "somente a espada em uma mão, na outra a Lei, e em torno de vós os Brasileiros cordatos, nos tornará à tranqüilidade pública" “ ${ }^{64} \mathrm{O}$ mesmo defendia Hum que só trabalha para a tranquilidade, sugerindo que "Cidadãos Pais, Esposos, e Filhos, empunharão as armas a salvar os mais caros objetos de Pátria, Liberdade, Honra, e bens, ameaçados por ímpios bebedores de sangue". ${ }^{65}$ Já O indignado com tanta impudencia, aludindo às distorções exageradas da Nova Luz Brasileira, interpelava seu redator a declarar "quem são os mortos na noite de 28 de Setembro, além do Araujo, de Pernambuco, caixeiro, do Maranhão, e de um Português; assim como de declarar a que família pertence a Sra. que também diz que morrera"; caso contrário, seria tido como um infame que, "mentindo impudentemente sobre fatos da maior publicidade, inventou demais essa para tornar sobre as Guardas o odioso de fatos, de que ele, e seus sequazes só são culpados". ${ }^{66}$ O Compadecido também ironizava, em duas cartas, a fictícia história da senhora morta no teatro, afirmando que se chamava dona Esperança Bárbara da Lampadosa e que só teria morrido depois, na Ilha das Cobras. ${ }^{67}$ Testemunha dos fatos, o Epaminondas acusava a "súcia luz-jurujuba" de desfigurá-los e, repetindo a versão do juiz de paz, a quem isentava de culpa, dizia que tudo fora provocado por um "grupo de moços de chapéu de palha, que pareciam comandados pelo Sr. Frias". ${ }^{8}$ Por fim, outro missivista queria saber a que inspirações obedeciam aqueles que, no dia 29, "reunidos à ralé mais cível da nossa população e a pretos descalços, corriam as ruas, perpetrando assassínios com a ferocidade de canibais"; para ele, os sucessivos distúrbios e as doutrinas pregadas por "corifeus bem conhecidos" apontavam os agentes da desordem,

\footnotetext{
${ }^{63}$ Carta no Jornal do Commercio, $\mathrm{n}^{\circ}$ 28, de 5/10/1831, e no Diario do Rio de Janeiro, $\mathrm{n}^{\circ} 3$, de 4/10/1831.

${ }^{64}$ Diario do Rio de Janeiro, no 23, de 28/9/1831.

${ }^{65}$ Ibidem, n ${ }^{\circ} 4$, de 5/10/1831.

${ }^{66}$ Jornal do Commercio, $\mathrm{n}^{\circ} 28$, de 5/10/1831.

${ }^{67}$ Astréa, ${ }^{\text {os }} 754$, de 6/10/1831, e 758, de 15/10/1831.

${ }^{68} \mathrm{O}$ Independente, $\mathrm{n}^{\mathrm{o}} 45$, de 4/10/1831.
} 
responsáveis por "fazer-nos passar aos olhos do Mundo civilizado, como um Povo indigno da Liberdade".${ }^{69}$ Contundentes eram, portanto, as manifestações de repúdio da opinião pública fluminense às intervenções diretas dos exaltados; mas estes seguiriam tentando obter assim o controle do espaço público, empreendendo novas revoltas.

\section{O teatro da política}

Conhecido o evento, convém assinalar alguns aspectos na análise da revolta. ${ }^{70} \mathrm{O}$ primeiro refere-se aos participantes do movimento e à sua composição social. Como visto, para os defensores do governo e da ordem autoridades diversas, publicistas moderados e cidadãos comuns - a multidão de manifestantes seria formada por uma plêiade de degenerados: "anarquistas", "agitadores", "amotinadores", "malfeitores", a "ralé mais cívil da nossa população", "Grupos de negros, e pardos da ínfima classe, rotos, e meios descalços", "pretos descalços", "ímpios bebedores de sangue", a "súcia luzjurujuba", "soldados da Nova Luz". ${ }^{71}$ Não há dúvida de que houve participação expressiva de indivíduos de baixa condição social, inclusive escravos. ${ }^{72} \mathrm{Di}$ ferentes tipos de relatos - judiciais, governamentais, jornalísticos - apontam para isso e, como será visto adiante, tais pessoas tinham motivos suficientes para aderirem a revoltas, vendo aí uma oportunidade de expressar seus descontentamentos e anseios. Também é claro que o estado de comoção social em que se davam os distúrbios propiciava que ladrões, salteadores, desocupados, agitadores e arruaceiros oportunistas aproveitassem a confusão reinante e se juntassem aos demais manifestantes apenas para fins pessoais escusos, que nada tinham a ver com os propósitos do movimento. Por outro lado, tais qualificações refletiam também estereótipos sociais eivados de preconceitos, calcados na concepção distintiva de povo e plebe. ${ }^{73}$ Nada mais lógico, então,

${ }^{69}$ Ibidem, n ${ }^{\circ} 46$, de $7 / 10 / 1831$.

70 Tomam-se aqui como referência as sugestões metodológicas propostas por George Rudé, em seu estudo sobre a multidão pré-industrial. Cf. George Rudé, A multidão na história: estudo dos movimentos populares na França e na Inglaterra, 1730-1848, Rio de Janeiro, Campus, 1991, p. 9-10.

${ }^{71}$ Visão semelhante tinha Moreira de Azevedo (op. cit., p. 353-354), ao classificar os manifestantes de "turbulentos" e "facciosos".

72 Apoiada sobretudo em fontes policiais, Gladys Ribeiro (op. cit., p. 281-299) demonstrou o quanto esta população subalterna - livre e cativa - se encontrava agitada nas ruas, antes e depois da Abdicação, participando ativamente dos pequenos e grandes conflitos de rua na Corte.

${ }^{73}$ Ver, a respeito, Ilmar Rohloff de Mattos, O Tempo Saquarema: a formação do Estado imperial, $2^{a}$ ed., São Paulo, Hucitec, 1990, especialmente p. 125 e 259. 
do que atribuir à plebe - repositório da escória da sociedade, manipulada pelos anarquistas demagogos da facção exaltada - a participação ativa na revolta. Além disso, esta era igualmente uma estratégia eficaz utilizada pelos moderados e pelo governo para denegrir qualquer ação de protesto e seus participantes e, assim, justificar a repressão, sobretudo aos exaltados. Contudo, é também evidente que, além da massa oriunda do mundo da desordem (homens livres pobres) e do mundo do trabalho (escravos), um grande contingente de indivíduos letrados e com ocupação definida, provenientes, em geral, das camadas médias urbanas (e do mundo do governo) participou ativamente deste e de outros movimentos. ${ }^{74}$ Os próprios líderes, neste caso, eram oficiais militares, como o major Miguel de Frias e Vasconcellos, os tenentes Antonio Joaquim Bacellar, Honorio José Ferreira e Leopoldo Frederico Thompson, e os alferes Francisco Joaquim Bacellar, João do Rego Marques e José Alexandre, todos do Exército.

Convém salientar o papel dos boatos na agitação dos ânimos, que precederam esta e outras ações semelhantes. Em uma cultura fortemente marcada pela oralidade, constituíam um mecanismo fundamental de transmissão de informações e idéias. Mesmo quando não passavam de alardes infundados, eram sempre elementos mobilizadores, produzindo movimentos de ação e reação, como bem ilustra a polêmica gerada em torno do caso Hum que está prompto para tudo.

$\mathrm{Na}$ interpretação de moderados e exaltados, prevalecia uma visão conspiratória dos distúrbios: estes eram imputados por cada facção, representada na imprensa, a uma suposta trama ou intriga urdida pelo rival, cujos agentes seduziriam ou subornariam hordas oriundas da escória da sociedade, com instintos criminosos, visando realizar interesses particulares e egoístas, e promover a ruína do outro. Se para os moderados a revolta seria expressão da anarquia na luta contra a ordem, para os exaltados seria a manifestação da liberdade no embate contra o despotismo. De um lado, as denúncias de complô eram uma estratégia retórica de depreciação do oponente, sob acusação de expediente, ${ }^{75}$ que servia para justificar ações repressivas. Contudo, de outro (daí sua eficácia), eram crenças inerentes à cultura política que informava aqueles grupos. ${ }^{76}$

\footnotetext{
${ }^{74}$ Para os três mundos da sociedade imperial, cf. ibidem, p. 109-128.

${ }^{75}$ Cf. Chaïm Perelman e Lucie Olbrechts-Tyteca, Tratado da argumentação: a nova Retórica, São Paulo, Martins Fontes, 1996, p. 511-521.

${ }^{76}$ Raoul Girardet (Mitos e mitologias políticas, São Paulo, Companhia das Letras, 1987, capítulo 1) apontou a conspiração como um dos mitos políticos dos séculos XIX e XX, assinalando a função explicativa e mobilizadora exercida pela crença em poderosos grupos ou entidades, cujos membros (jesuítas, maçons, judeus, por exemplo) manipulariam secretamente desde o governante até o mais simples cidadão, visando à dominação.
} 
Mas é preciso ir além destas interpretações simplistas e analisar as motivações substanciais da revolta. Embora não houvesse um fator único a impelir igualmente todos os diferentes manifestantes, os distúrbios do teatro, como os demais da época, tinham caráter predominantemente político. Em primeiro lugar, foram motivados pelo controle do governo regencial, exercido pelos moderados, alijando os exaltados, que, como recompensa ao papel que tiveram na queda de Pedro I, se achavam no direito de ao menos compartilhar o poder com seus ex-aliados. O sentimento de desilusão e de terem sido traídos nessa partilha esteve, assim, na raiz da ação sediciosa promovida pelos exaltados, bem como a não-continuidade da Revolução em direção às reformas que defendiam e, ainda, às perseguições sofridas por conta de tais propostas e daquelas ações. No caso em questão, todos os principais envolvidos eram conhecidos militantes exaltados, em particular Miguel de Frias, que tivera papel de destaque no momento crucial da Abdicação e redigia um jornal federalista e republicano. O incidente fortuito entre o juiz de paz e dois oficiais brigões serviu de pretexto para desencadear protestos políticos violentos contra o governo e as autoridades. Não faltaram gritos de viva à Assembléia Constituinte e à república, e de abaixo a Regência e o ministro da Justiça.

Mesmo no caso de fatores de outra natureza, ou mais específicos de determinado segmento social, transparece o caráter primordialmente político da ação. É o que se nota a respeito dos militares. Eram antigas e notórias as ligações dos exaltados com as tropas, particularmente a baixa oficialidade e os soldados. Cientes do potencial desses homens para seus fins revolucionários, os exaltados exploravam, em seus jornais, os objetos de descontentamento dos militares, criticando os maus-tratos e os castigos corporais, o recrutamento forçado, a presença de portugueses e estrangeiros nas tropas, a transferência de batalhões, as baixas forçadas e a prisão dos envolvidos nas sedições, ao mesmo tempo em que conclamavam os militares a saírem em defesa da pátria e a não servirem de instrumento do despotismo. ${ }^{77}$ Além disto, empreendiam campanha sistemática de aliciamento diretamente nos quartéis, preocupando as autoridades e os moderados. Em todas as revoltas promovidas pelos exaltados há várias evidências desta ação. Na aqui enfocada, observa-se que, ao deixar o teatro, manifestantes civis e militares seguiram para o quartel do $5^{\circ}$ Batalhão de Caçadores e conseguiram sublevá-lo; depois, seduziram alguns guardas municipais que abordaram na rua.

${ }_{77}$ Cf. Marcello Otávio Neri de Campos Basile, “O Império em construção...”, op. cit., p. 218-220. 
Outro traço marcante neste e em outros movimentos é o antilusitanismo. Elemento importante da cultura política brasileira do período, apresentava várias faces, como a associação dos portugueses ao colonialismo, ao absolutismo ou à Restauração (representando ameaça à Independência e à identidade nacional), à alta do custo de vida (frente às suas atividades de comerciantes e locatários de imóveis, mas também acusados de agiotas, açambarcadores e atravessadores de víveres) e à concorrência no mercado de trabalho (quase monopolizavam certos ofícios, como o de caixeiro). ${ }^{78}$ Além das questões políticas e socioeconômicas embutidas, havia um problema étnico, como demonstrou Gladys Ribeiro, patenteado nas alcunhas de pés-de-cabra, cabra ou cabrito, dadas pelos portugueses aos brasileiros, como insultos referidos aos pardos. A mesma autora toma o movimento do teatro como exemplo paradigmático dos conflitos antilusitanos em toda sua amplitude (e das rixas entre os diferentes corpos militares). ${ }^{79}$ De fato, os distúrbios foram gerados a pretexto de um suposto privilégio dado pelo juiz de paz local ao oficial adotivo que brigara com o oficial brasileiro, permitindo àquele, segundo se espalhou, que escapasse à prisão. Os lances subseqüentes, a título de vingar a vexação sofrida e o sangue brasileiro derramado, tiveram em primeiro plano (sob um fundo de protesto contra o governo moderado) o conflito entre brasileiros e portugueses (estes representados pela Guarda Municipal); e a própria velocidade com que tudo ocorreu e as dimensões tomadas demonstram bem que este era um problema candente. É significativo que os rebeldes exaltados que, na madrugada de 29 de setembro, abordaram esquadras da Guarda Municipal tenham logo perguntado a seus integrantes se eram brasileiros e, diante da resposta positiva, tentado coagi-los a se unirem ao grupo, ameaçando, inclusive, matar os que identificavam como chumbos.

Convém frisar que classificar um movimento de exaltado ou dizer que este grupo o promoveu não significa ignorar ou minimizar as motivações e os interesses diversos de outras categorias sociais também atuantes. Significa, sim, reconhecer que tais segmentos não tinham articulação necessária para desencadeá-lo sozinhos e que, portanto, precisavam aproveitar os momentos

\footnotetext{
${ }^{78}$ Sobre o antilusitanismo na Corte, cf. Gladys Sabina Ribeiro, op. cit., especialmente o capítulo 3; e Lenira Menezes Martinho, "Caixeiros e pés-descalços: conflitos e tensões em um meio urbano em desenvolvimento", Lenira Menezes Martinho e Riva Gorenstein, Negociantes e caixeiros na sociedade da Independência. Rio de Janeiro, Secretaria Municipal de Cultura, Turismo e Esportes - Departamento Geral de Documentação e Informação Cultural - Divisão de Editoração, 1993, parte 1, sobretudo capítulo 4.

${ }^{79}$ Gladys Sabina Ribeiro, op. cit., p. 290-293.
} 
de cisão violenta entre as elites - como a que então dividia moderados, exaltados e caramurus - para assim expressar seus anseios, colocando-se sob a bandeira de uma facção insurgente. Tanto que, após o desaparecimento desses grupos e a recomposição das forças políticas no sentido de uma maior unidade (ou de uma melhor administração dos conflitos), não mais ocorrem movimentos assim na Corte; e é claro que isto não se deve apenas à maior organização do aparato repressivo do Estado imperial a partir do Regresso. Além disto, é preciso reconhecer a mínima capacidade dos exaltados de promoverem estas ações, visto que, ao contrário daquelas camadas sociais, constituíam um grupo político com razoável grau de organização, que dispunha de diversos canais de atuação e mobilização, apelando, inclusive, para aqueles segmentos. Assim, falar em revoltas exaltadas significa dizer que foram estes seus condutores, e não que tenham sido seus únicos agentes.

Seja como for, os movimentos contestatórios da Corte expressam bem o que Hilda Sabato chamou de "cultura da mobilização", ${ }^{0}$ a valorização das manifestações públicas coletivas como forma legítima de ação política, resultado de uma nova cultura política, calcada nas idéias liberais. Esta politização das ruas era a forma viabilizada de dar vazão a uma demanda política e social e a um potencial participativo que não encontravam espaço dentro dos canais institucionais de atuação política. Para além de uma cidadania formal estadocêntrica, estabelecida de cima para baixo, sob a tutela do Estado imperial, ${ }^{81}$ desenvolvia-se uma prática informal de cidadania, construída de baixo para cima, mediante a participação ativa das mais diversas camadas sociais nas instâncias de ação política do espaço público. ${ }^{82}$ Ao se definirem como um lugar de exercício da cidadania, agindo em nome de direitos que julgavam legítimos, os movimentos de protesto da Capital imperial, embora não tivessem cunho nacionalista, constituíam um dos eixos de formação política de uma incipiente nacionalidade, produzida igualmente de baixo para cima, ao promoverem a exaltação da pátria e, bem ou mal, um sentimento de compromisso dos indivíduos com a nação, pelo lado quer dos manifestantes, quer de seus oponentes, quer mesmo daqueles que simplesmente foram espectadores dos

${ }^{80}$ Hilda Sabato, La política en las calles: entre el voto y la movilización - Buenos Aires, 1862-1880, Buenos Aires, Sudamericana, 1998, terceira parte, sobretudo capítulos 7 e 10.

${ }^{81}$ Cf. José Murilo de Carvalho, “Cidadania: tipos e percursos”, Estudos históricos, v. 9, $n^{\circ} 18$-justiça e cidadania, Rio de Janeiro, CPDOC - Fundação Getúlio Vargas, 1996, p. 339-340 e 354-356.

${ }^{82}$ Cf. Bryan S. Turner, "Outline of a theory of citizenship", Bryan S. Turner e Peter Hamilton (org.), Citizenship: critical concepts, v. I, Londres / Nova York, Routledge, 1994, p. 209-210 e 215-218. 
acontecimentos. Para tanto, muito contribuiu também a ação mobilizadora da imprensa, ao amplificar, por via escrita e oral, a discussão em torno de tais valores e ações. ${ }^{83}$ Todavia, a repressão bem-sucedida a essas manifestações, que praticamente desaparecem na Corte a partir de 1835, e o concomitante esfacelamento dos grupos de oposição que os promoviam constituíram um golpe fatal no tortuoso processo de desenvolvimento da cidadania e da nacionalidade por esse caminho.

${ }^{83}$ Para uma análise da questão nacional a partir dos movimentos políticos e de suas relações com a cidadania, ver John Breuilly, "Abordagens do nacionalismo", Gopal Balakrishnan (org.), Um mapa da questão nacional, Rio de Janeiro, Contraponto, 2000, p. 172-176. A construção da nacionalidade de baixo para cima é enfatizada por Eric J. Hobsbawm, Nações e nacionalismo desde 1780: programa, mito e realidade, Rio de Janeiro, Paz e Terra, 1990, p. 20. E o papel da imprensa na formação das comunidades politicas imaginadas é sublinhado por Benedict Anderson, Nação e consciência nacional, São Paulo, Ática, 1989, capítulos 3 e 4. 